\title{
The last frontier of globalization: Trade and foreign direct investment in healthcare
}

\author{
Oded Shenkar ${ }^{1}$, \\ Guoyong Liang ${ }^{2}$ and \\ Rakefet Shenkar ${ }^{3}$
}

${ }^{7}$ Fisher College of Business, The Ohio State University, Columbus, $\mathrm{OH} 43210$, USA $^{2}{ }^{2}$ Division on Investment and Enterprise, United Nations Conference on Trade and Development, Palais des Nations, 1211 Geneva, Switzerland; ${ }^{3}$ Boonshoft School of Medicine, Wright State University, Dayton, $\mathrm{OH} 45435$, USA

\section{Correspondence:}

G Liang, Division on Investment and Enterprise, United Nations Conference on Trade and Development, Palais des Nations, 1211 Geneva, Switzerland e-mail: Guoyong.liang@unctad.org

Disclaimer: The views expressed in this article are those of the authors only and do not necessarily represent those of their affiliated organizations.

Received: 16 June 2020

Revised: 23 March 2021

Accepted: 5 April 2021

Online publication date: 17 May 2021

\begin{abstract}
Internationalizing far later than other sectors, healthcare has seen trade and foreign direct investment (FDI) grow in recent years. While part of the service economy, healthcare has unique features that distinguish it from other service sectors and imprint on its globalization and spillover patterns. In this paper, we review the trends in healthcare internationalization, its drivers, and the obstacles standing in the way. We outline the special characteristics of the healthcare sector and how they affect the positive and negative spillovers from trade and FDI for home and host-countries. Implications for international business theory, research, and policy are delineated.
\end{abstract}

Journal of International Business Studies (2022) 53, 362-374.

https://doi.org/ | 0.1057/s4 I 267-021-00439-w

Keywords: healthcare; trade flows; foreign direct investment; medical tourism; spillovers

\section{INTRODUCTION}

Healthcare has been one of the last sectors to internationalize, trailing not only manufacturing but also many other services. The sector's globalization is picking up steam, however, with trade and foreign direct investment (FDI) growing. In 2005, the global value of international trade in healthcare services was estimated at US\$33 billion (Mortensen, 2008), doubling between 2003 and 2010 (Lautier, 2014). UNCTAD data show global FDI stock growing from $\$ 1$ billion in 1990 to $\$ 38$ billion in 2015 . By 2018, the combined FDI stock in the US and the EU surpassed \$24 billion, while total accumulated FDI flows to China and India reached $\$ 9$ billion in 2020.

International business (IB) started with a manufacturing focus, and, while research expanded to service multinational enterprises (MNEs) (Boddewyn et al., 1986; Campbell \& Verbeke, 1994; Goerzen \& Makino, 2007), scholarship is scant, and more so when it comes to healthcare. Following Toyne and Nigh's (1998) comment on the value of contextualization for IB theory development, we tap the opportunity that the sector, a frontier of globalization, offers.

In this paper, we review healthcare internationalization, its patterns, drivers, and roadblocks. We assess the uniqueness of the healthcare sector, look at the positive and negative spillovers from trade and FDI, and weigh implications for IB. Our key research question is how healthcare's unique features explain its late 
internationalization as well as trade and FDI patterns. In addition to bringing to light a hitherto neglected IB research domain, we seek a number of contributions. First, we add to the debate on why MNEs exist. Second, we showcase the mutuality of home- and host-country spillovers in two-way trade and investment flows. Third, we contribute to industry characterization by pinpointing the ramifications of values and quality capture. Fourth, we identify data points and research directions that will be useful for IB studies on healthcare. Finally, we chart policies concerning a sector whose worth has been painfully elucidated during the COVID-19 pandemic.

\section{HEALTHCARE: SECTORAL CHARACTERISTICS AND INSTITUTIONAL ATTRIBUTES}

The prominence of sectoral features in shaping internationalization path and scope has long been underscored (Dunning, 1980; Hitt et al., 2006; Markusen, 1984; Oh et al., 2019). Healthcare is a service sector, a segment whose special features, e.g., intangibility, inseparability, heterogeneity, customizability, and perishability, have been flagged (Boddewyn et al., 1986; Mills \& Morris, 1986). Services, as Dunning and McQueen (1982) note, are less location-sensitive, exceptions notwithstanding. Still, even among services, healthcare stands out (Table 1).

First and foremost, healthcare is entrusted with human life, a sanctified individual and social value (Cutler \& Richardson, 1998). As Hall and Jones (2004: 39) write, "...life is extremely valuable, and, as we get richer and richer, the most valuable channel for our spending is to purchase additional years of life." Even medical interventions that are not lifesaving can greatly impact life quality. Life and safety are also paramount in aviation, but in medical care there is no aspiration for "zero mortality". While quality control is also important in hospitality (Casson, 1982), it is more so in healthcare, where consequences of subpar performance are ominous.

Second, Javalgi et al. (2003) divide services into three groups (contact-, vehicle-, and asset-based), and healthcare belongs to the first. Despite remote $\mathrm{x}$-ray reading and the advance of telemedicine, healthcare is contact-based (Clark et al., 1996) and locally confined. Like social work agencies, healthcare outfits are "human service" or "people-processing organizations" (Hasenfeld, 1972; Uner, Cetin, \& Cavusgil, 2020), where the client is not only an active participant in service delivery but is at its very center. In healthcare, the intensity of the contact and its repercussions, are an order of magnitude higher.

Third, from an organization theory perspective, healthcare delivery is complex. Healthcare services are heterogeneous, ranging from clinical consultation to the diagnosis and treatment of a fatal disease, based on multiple bodies of knowledge residing in dozens of subspecialties. Thompson (1967) classifies technology in hospitals as "intensive", as opposed to "pooled" or "sequential", as patients are shuffled back and forth between units and providers whose interdependent responsibilities overlap or complement. The need for customization based on medical and personal conditions bumps against regulations and the standardization sought by large chains and

Table 1 Sectorial characteristics: Manufacturing, services, and healthcare

\begin{tabular}{llll}
\hline & Manufacturing & Services & Healthcare \\
\hline $\begin{array}{l}\text { Separability from users } \\
\text { Intensity of users contact }\end{array}$ & Yes & No & No \\
Value of good/service & Low to high & Low to high & Very high \\
& & & Medium to extremely \\
high & Perishable \\
$\begin{array}{l}\text { Perishability } \\
\text { Inventory }\end{array}$ & Non-perishable & Perishable & No \\
$\begin{array}{l}\text { Ratio of skilled staff } \\
\text { Government regulation }\end{array}$ & Low to medium & No & Extremely high \\
& Low (e.g., garments) to high (e.g., & Low (e.g., hotel service) to high (e.g., & Extremely high \\
$\begin{array}{l}\text { Difficulty to ascertain quality } \\
\text { Involvement of religious } \\
\text { organizations }\end{array}$ & Relatively low & air travel) & Extremely high \\
Globalization & Low & Low to moderate & Moderate \\
& High & Moderate (e.g., law) to high (e.g., & Very low \\
\hline
\end{tabular}


government bursars, adding complexity, as does the power of healthcare professional associations which compete for control with organizational hierarchy in hospitals and clinics (Sorensen \& Sorensen, 1974). Given the sophisticated knowledge base and limited transparency, it is difficult to evaluate the quality of medical services (Zeithaml, 1981), especially for a layperson.

Fourth, regarded a public good, a human right, paid for, directly or indirectly, and often also delivered by the state or its agencies, healthcare has a relatively low degree of "commercialization". Investment, from a transaction costs perspective, is asset-specific, as hospitals can hardly be converted to other uses (Lethbridge, 2011). Public ownership in healthcare is widespread, and private and forprofit service usually play a supplementary role. High entry barriers make healthcare less "tradable" and "investable" than other services, as trade and FDI are strictly regulated. More often than not, government-provided or -subsidized insurance, such as the US Medicare, does not apply beyond a country's borders. Even where not handled by and/ or paid for by government (a public or single payer system), the state retains a role overseeing the sector. Licensing is more onerous than in most other services (Vandermerwe \& Chadwick, 1989), and the state is involved in setting and negotiating prices.

While all sectors are sensitive to cultural and institutional cues, the sanctity of human life and the nature of delivery make healthcare more so. As opposed to the limited engagement in, say, business consulting, medical conditions bear on the entire family, increasing the importance of cultural and religious compatibility (Fetscherin \& Stephano, 2016). The larger "contact surface" and the intense contact between provider and consumer amplify home- and host-country differences, setting the stage for conflictual friction (Shenkar, Tallman, Wang, \& Wu, 2020). The impact of institutional differences is amplified by the heavy government role in terms of strict regulation, major state ownership, and payer role, which, together with customization, lower the potential for system compatibility.

\section{HEALTHCARE INTERNATIONALIZATION: MODES AND PATTERNS}

Compared with manufacturing, services have low internationalization: they account for over 70 per cent of the world economy but only a quarter of global trade. Even compared with the services and social infrastructure sectors, healthcare has been late to globalize (UNCTAD, 2004). This latecomer status is related to the aforementioned features of the sector, as well as broader obstacles to trade in services (Samiee, 1999). The rising, though still modest, international trade in healthcare is consistent with an overall increase in globalization. At the firm level, healthcare internationalization is explained by monopolistic competition, location advantages, and transaction costs (Caves, 1971; Dunning, 1980; Hymer, 1960). Patterns are generally consistent with the Uppsala model (Johanson \& Vahlne, 1977): a hospital chain may start by serving foreign patients before establishing a foreign affiliate. Given the complexity and high barriers, success requires the leveraging of dynamic capabilities and trust (Fregidou-Malama \& Hyder, 2015; Uner et al., 2020), the latter having an amplified role in the sector.

\section{Modes of International Service Provision}

In a broad sense, healthcare actors are those catering to the end consumer, e.g., hospitals and clinics; goods producers, e.g., medical device manufacturers; service suppliers, e.g., drug distributors; private insurers; and premise providers and maintainers (Holden, 2005). We focus on the first group whose primary focus is the delivery of healthcare services, including internationally via four Modes defined by the World Trade Organization (WTO)'s General Agreement on Trade in Services (GATS).

Applying the standard classification to healthcare, Chanda (2002) sees Mode 1 as the cross-border supply of healthcare services, including the "shipment of laboratory samples, diagnosis, and clinical consultation via traditional mail channels, as well as electronic delivery of health services, such as diagnosis, second opinions, and consultations" (2002: 158). Growth in this mode benefits from fewer obstacles and technological development. Expert consultations can now be delivered electronically, bypassing travel for provider or patient, limiting regulatory burden, and reducing wage costs, as with an Indian radiologist who reviews a US-generated CT scan.

Mode 2 is the consumption of healthcare services abroad, namely the foreign travel of patients for diagnosis and treatment, labeled "medical tourism". The OECD distinguishes medical tourism from "health tourism", the latter involving nonhospital facilities and complementary or alternative medicine rather than core intervention (Lunt et al., 
2010). Treatments include cosmetic surgery, dentistry, cardiology/cardiac surgery, orthopedic surgery, bariatric surgery, fertility/reproductive, (organ, cell, and tissue) transplantation, eye surgery, and diagnostic. For example, US patients travel for "orthopedic surgery, cosmetic surgery, cardiology (cardiac surgery), oncological care, and dentistry" (CDC, 2018).

Mode 3 is commercial presence (akin to FDI): "the establishment of hospitals, clinics, diagnostic and treatment centers, and nursing homes" (Chanda 2002: 159). Often, healthcare FDI is prohibited or limited to ownership categories (e.g., private), type of operation (e.g., clinics vs hospitals) or treatment type (e.g., plastic surgery). Foreign investors face close scrutiny, and the ability to bring medical staff is limited by licensing to assure quality and to protect domestic providers. Apart from equity investment, foreign healthcare providers establish commercial presence via nonequity modes, as discussed later.

Mode 4, the presence of natural persons, involves the provisional travel of healthcare professionals to provide care abroad. While reports exist on the travel of foreign staff to provide pro bono care or offer training in a developing country, we lack data on compensated, temporary expatriates who travel to provide treatment.

Official statistics on the four modes of service provision, including their sectorial breakdown, are limited. Some compilation efforts have been made at the national, regional, and global levels based on balance of payments data and foreign affiliates statistics (Mann, 2017; Rueda-Cantuche, Kerner, Cernat, \& Ritola, 2016; Wettstein et al., 2019). Regarding medical tourism, Patients Beyond Borders (2015) estimates a market of $\$ 46-72$ billion, based on 7-11 million cross-border patients, spending \$3,800-6,000 per visit. The World Tourism Organization (2016) sees a market of 14 million medical tourists, growing by 25 percent a year. Those estimates must be taken with a grain of salt: they are not systematically collected, travelers rarely indicate entering a country for treatment purposes, and nor do hospitals have to report foreign patient admission.

\section{International Trade Flows}

The rising international trade in healthcare has been driven by an overall increase in globalization, growing and cheaper mobility, access to data on treatment options abroad, electronic transfer of medical records, remote follow-up, regulatory easement in insurance and licensing, and ethnic migrant clustering that creates a social support network for incoming patients. Among the regulatory changes, for instance, European Court of Justice rulings allow EU residents to receive treatment in member states other than their own under certain circumstances (Bertinato et al., 2005). At the individual level, healthcare trade is subject to perceptions concerning costs and benefits (Chaulagain, Pizam, \& Wang, 2020).

Trade flows run from developing to developed nations and vice versa. The flow of developing nation patients to a developed country is the older, rooted in low standards in developing nations (Reading, 2010), where providers are presumed to provide poor quality - many lack formal training, and skill upgrade is limited, as staff leave for greener pastures. In the US, the total number of inbound foreign-trained doctors surpassed 200,000 in the mid-2010s; the largest six sources were all developing or emerging economies. This number does not include provisional assignments. For example, Cuba has 28,000 physicians and nurses on temporary duty abroad, and medical services made up 46\% of Cuban exports in 2019 (Economist, 2020). Rajshekhar et al. (2001) found a country-of-origin effect for services, especially where little is known about a product (HarrisonWalker, 1995). Growing income in emerging economies and an increase in high-end, private insurance programs further support this flow.

The inverse patient flow from developed to developing markets is more recent but increasingly robust. Lautier (2014) reports that, between 1997 and 2010, exports of healthcare services from developing to developed markets have grown faster than in the other direction (12.3 vs 5.0 percent). Costa Rica, Singapore, and Thailand are top on the global medical tourism index (Fetscherin \& Stephano, 2016). Malaysia, Thailand and Singapore are magnets in the Association of Southeast Asian Nations (ASEAN), with an estimated 4 million patients in 2017 (ASEAN Secretariat \& UNCTAD, 2019). With 660,000 medical tourists arriving in 2019, Turkey is also a top-ten destination, aided by a large diaspora (Dalen \& Alpert, 2018; Uner et al., 2020). Specialization is also at play, for instance, Thailand and India in orthopedic and cardiac surgery, and Eastern European countries in dental surgery (Smith et al., 2011).

Al-Amin et al. (2011: 206) explain the drivers of developed-to-developing flow as "lower costs of care, absence of rationing as prevalent in many 
developed countries with universal healthcare, access to procedures proscribed by regulatory authorities in home countries, and belief in alternative systems of medicine". Significant cost differences, e.g., in heart-valve replacement (Smith et al., 2009) and inpatient knee surgery (Mattoo \& Rathindran, 2006), entice demand. Patients in a single payer system or on a limited private plan are motivated by wait time, especially for elective care or procedures, such as kidney transplants. An increase in physicians with developed country degrees helps allay quality concerns, as does accreditation (Lunt et al., 2010). Improved facilities are available to foreign patients thanks to private investment, while governments invest in infrastructure and ease visa procedures.

\section{Foreign Direct Investment}

Global FDI stock in health services rose from \$1 billion in 1990 to $\$ 38$ billion by 2015, according to preliminary UNCTAD data. Developed countries account for most (Herman, 2009; Khorana, 2016), but the share of developing and transition economies exceeded $20 \%$ by 2015 . ASEAN, Brazil, China, and India are major developing host economics, while the EU, the UK, and the US are their developed equivalents. The US is by far the largest host: its inward FDI stock amounted to $\$ 9.7$ billion in 2015, one fourth of the global total; by 2018, it had reached $\$ 16$ billion. To put it in perspective, inward FDI stock in the US totaled $\$ 4.3$ trillion in 2018 , with $\$ 2.6$ trillion in services.

Among developing regions, Asia is the primary FDI host. Many ASEAN members permit full foreign equity ownership in hospitals, and the private sector accounts for a high share (ASEAN Secretariat \& UNCTAD, 2019). In China, international joint ventures are allowed in healthcare, and accumulated FDI inflows in the sector reached $\$ 1.7$ billion between 2006 and 2020. With accumulated inflows at $\$ 6.9$ billion during 2000-2020, India's attractiveness lies in high demand versus inadequate supply, rising disposable income of a growing middle class, and government policies that promote healthcare FDI (Govinda \& Poornima, 2020). A major recipient in Latin America, Brazil has received increasing FDI in healthcare since its opening in 2015, and inflows surged in 2019. In the least developed countries, particularly in SubSaharan Africa, where investment is urgently needed, private foreign participation is limited.
Healthcare FDI in developed nations, the main destination in 2003-2018, was mostly by mergers and acquisitions, explained by established facilities and the client base. In contrast, eight of the largest ten greenfield healthcare investments during the same period were in developing countries, with most investors from higher income countries. The eight projects brought in a total investment of \$3.6 billion.

Healthcare MNEs invest and operate in general hospital care, specialized care, and specific diagnosis/treatment (Lethbridge, 2015). They range from public, non-for-profit hospitals and clinics to private, for-profit firms, and operators of multiple medical facilities, sometimes invested in by private equity funds. In the global Fortune 500 of 2019, two MNEs stand out: No. 241, US-based HCA Healthcare, with revenues of $\$ 46.7$ billion, manages 185 hospitals and 119 surgery centers, including 10 UK-based facilities, and No. 313, Germanybased Fresenius, with revenue of $\$ 39.6$ billion, is more diversified and international, operating in over 100 nations. Emerging country players are now entering both developing and developed markets. In ASEAN, several international hospital operators, such as IHH Healthcare Berhad (Malaysia) and Thonburi Hospital Group (Thailand), are active players in the region, including China and India. However, the number of healthcare MNEs looks much lower than in other sectors, as does their magnitude, something we discuss later.

Finally, non-equity modes of foreign participation in healthcare include management contracts, contractual joint ventures, and franchising, often involving collaboration between foreign and domestic hospitals. This is somewhat surprising, since the literature on service internationalization presumes that non-equity investment will be limited because it does not permit close monitoring and control to ensure quality (Boddewyn et al., 1986; Dunning \& Norman, 1983; Pérez, 2020). Encouraged by the UK government, several UK National Health Service hospitals have set up overseas branches on a franchising basis, generating an export business of $£ 100$ million during 2016-2017 (Telegraph, 2018). In the US, international arms of leading US academic medical centers, such as Partners Harvard Medical International and Johns Hopkins Medicine International, have forged partnerships in developing countries. 


\section{HOME- AND HOST-COUNTRY SPILLOVERS}

Trade and FDI are known to generate spillovers, although the broad literature focuses more on FDI (see Stevens et al., 2013, for an exception), on the impact on the host rather than the home country, and on the flow from developed to developing countries, where spillovers augment productivity (Grossman \& Helpman, 1991). Hymer (1960) recognized FDI as a comprehensive bundling of resources (e.g., capital, technology, managerial knowhow) that allow MNEs to compensate for their weaker local knowledge and to generate positive spillovers primarily via technology transfer to a subsidiary and from there to local players (Koizumi \& Kopecky, 1977). Endogenous growth theory links externalities to economic growth (Romer, 1986), enhancing interest in FDI's indirect impact, primarily spillovers. FDI spillovers take place via competition, demonstration and simulation, personnel mobility, and enterprise spinoffs, as well as linkages between foreign and domestic firms, both vertical and horizontal (Liang, 2004). Most studies on FDI spillovers focus on productivity, although non-productivity spillovers have been examined (Aitken, Hanson, \& Harrison, 1994; Buckley et al., 2002).

Positive and negative spillovers occur for both home and host-countries, yielding an ongoing debate (Blomström, 1989; Damijan et al., 2013). Aitken and Harrison (1994) found improved productivity in a host-country when foreign participants join local firms in a joint venture but not under other modes. A number of studies found weak evidence for a host-country's positive FDI spillovers on labor productivity (e.g., Haddad \& Harrison, 1993; Ruane \& Ugur, 2004), although FDI has been found to enhance total factor productivity (Hejazi \& Safarian, 1999). Smeets (2008) identified positive FDI spillovers for host-countries, while Wei et al. (2008) found positive spillovers for both host and home nations. Du et al. (2012) found that FDI did not generate productivity spillovers via horizontal linkages, but did so via forward and backward vertical links; Havranek and Irsova (2012) found support for backward spillovers only.

Here, we consider spillovers as externalities from trade and FDI in healthcare, with positive and negative ramifications. For example, healthcare imports and FDI inflows can lead to either "crowding in" or "crowding out" of domestic firms, depending on market conditions, firm capabilities, and linkages. Figure 1 presents a conceptual framework to analyze potential spillovers for both home and host-countries. To clarify, in medical tourism (Mode 2), the home country is the nation whose patients travel to another country to receive care; it is the host-country that exports its services. In healthcare FDI (Mode 3), the home country is the country whose MNEs and/or agencies invest and operate medical facilities abroad, whereas the hostcountry is where these facilities are physically located. The contents of the four cells focus on trade spillovers.

\section{Home-Country Positive Spillovers (Cell 1)}

\section{Positive spillovers from trade}

The flow of domestic patients abroad (an export of the counterpart nation) lowers pressure on domestic facilities, resulting in lower costs, shorter wait time, and more time with patients (presumably leading to higher quality) as physician to patient ratios improve. This holds true for both developed and developing nations, but the potential benefits to the latter are greater, given weaker infrastructure. Developing countries may encourage patient outflow to alleviate resource constraints, whereas developed nations will be happy to shorten treatment queues without having to foot the bill. Developed countries with a large portion of uninsured patients can benefit from alleviation of social and political pressures to expand coverage, whereas those with a single payer system will gain from a shorter wait time for patients who stay at home.

\section{Positive spillovers from FDI}

Home countries that invest abroad directly or indirectly via private, publicly traded and nonprofit entities benefit from scale advantages and the referral of complex cases to domestic facilities, supporting employment and tax revenue. Homecountry players also benefit from horizontal and vertical linkages. While a developed country may not have much to learn from a local provider, there are still valuable lessons concerning patients' values and expectations which will serve it well when receiving medical tourists and treating immigrant population at home. Such engagement is also an opportunity to lower costs via scale and by learning "bottom of the pyramid" practices on logistics and back office operations. When the investment is in a developed market, a strategic investor may augment core knowledge, improving care. 


\begin{tabular}{|c|c|c|}
\hline & Positive & Negative \\
\hline Home Country & $\begin{array}{l}1 . \\
\text { + Pressure alleviation on domestic } \\
\text { system: shorter treatment wait } \\
\text { times; lower medical costs } \\
\text { + Reduced government expenditure } \\
\text { + Treatment for the underinsured }\end{array}$ & $\begin{array}{l}2 . \\
\text { - Money leaving the country } \\
\text { - Underutilization of capacity } \\
\text { - Providers' underemployment } \\
\text { - Loss of scale raises cost and } \\
\text { reduces efficiencies \& expertise } \\
\text { - Eroding faith in health system } \\
\text { - Disincentive to develop capacity } \\
\text { - Follow-up procedures' expense }\end{array}$ \\
\hline Host Country & $\begin{array}{l}\text { 3. } \\
+ \text { Creating centers of excellence } \\
+ \text { A model for domestic providers } \\
+ \text { Scale economies } \\
+ \text { Retention of medical providers } \\
+ \text { Creating positive country-of-origin } \\
\text { effects }\end{array}$ & $\begin{array}{l}4 . \\
\text { - Overstay/migration of patients } \\
\text { - Birth tourism } \\
\text { - Crowding out of local patients } \\
\text { - Resentment re foreign patients' } \\
\text { (perceived) priority } \\
\text { - Diverted public investment }\end{array}$ \\
\hline
\end{tabular}

Figure 1 Potential spillovers in international healthcare.

\section{Home-Country Negative Spillovers (Cell 2)}

\section{Negative spillovers from trade}

A drawback of patients leaving to obtain care in foreign countries is that of capital leaving the country to pay for the services, which is especially problematic for poorer nations short on resources and hard currency. More pronounced is underutilization of existing capacity, whose quality may degrade and costs rise with procedures turning less routine, e.g., to a point where it is not economical to buy equipment. This will lower the incentive to upgrade and might lead to closure of clinics and hospitals, many of which are already under strain, depriving segments of the population of timely access to advanced care. Medical staff may become unemployed or underemployed and less proficient as the volume of procedures is reduced, and as experts take on foreign postings. Overall, there may be an erosion of faith in the local system, as the election to seek treatment elsewhere by those who can afford it is interpreted as a vote of no confidence.

\section{Negative spillovers from FDI}

An investment in healthcare facilities abroad will mean not only less resources for investing at home but it is also likely to reduce the inflow of foreign patients who can choose a closer affiliate rather than travel abroad, resulting in loss of revenues not only for the domestic healthcare industry but also for ancillary services, such as lodging. The negative impact may be especially pronounced in developing and emerging economies that can ill afford the revenue loss. Although most such investment comes from private outfits, it is still a possible substitute for investment in local facilities that are often underequipped and understaffed, shortchanging patients who cannot afford a major medical center or are too ill to get there. This 
"hollowing out", well known in the manufacturing sector, may also have significant social repercussions.

\section{Host-Country Positive Spillovers (Cell 3)}

\section{Positive spillovers from trade}

Receiving medical tourists from abroad has multiple positives for a country, as it brings in revenues not only to the medical facilities but also to ancillary sectors, such as hotels, restaurants, and travel providers. The benefit is amplified by family joining the patient to provide logistic and emotional support. While the benefit accrues to both developing and developed nations, the revenue stream is vital for the former, especially if in need of hard currency. For developing nations, the flow brings an upgrading of skills and facilities to meet the higher expectations of developed country patients and the requirements of foreign accreditation, which will also benefit domestic patients.

\section{Positive spillovers from FDI}

By integrating global supply and demand to improve patient access or share professionals, hospital collaboration benefits developing nations (Glinos \& Wismar, 2013). Lesher and Miroudot (2008: 19) argue that "foreign presence in the services sector can have strongly positive direct and indirect effects in the economy" via horizontal and vertical (backward and forward) linkages. Elsewhere, a positive impact for horizontal linkages is found for small-scale, specialized clinic joint ventures (Outreville, 2007), which is inconsistent with findings on other sectors showing productivity spillovers from vertical rather than horizontal FDI (Du et al., 2012). This is not a surprise since complex and tacit knowledge transfers better in cohabitation. Suppliers benefit by using backward linkages to upgrade and expand their customer base, while competitors learn by observation and by recruiting affiliate staff (UNCTAD, 2001). Cheung and Lin (2004: 25) list "reverse engineering, skilled labor turnovers, demonstration effects, and supplier-customer relationships" as spillover channels, most of which apply to healthcare.

\section{Host-Country Negative Spillovers (Cell 4)}

\section{Negative spillovers from trade}

One of the potential negatives for the host-country that is a recipient of medical tourists is pressure on local facilities, with foreign patients "crowding out" local patients. Even where this is not the case (e.g., where dedicated facilities are built for foreign patients), the influx is likely to increase social friction as locals sense discrimination and attribute long wait time and/or poor quality to diversion of resources away from their needs, as qualified staff in public hospitals may switch to higher paying jobs in private affiliates. Another problem, found in developed countries that are migration magnets, such as Canada, is the emergence of "birth tourism", where foreigners arrange, mostly via intermediaries, to give birth as a path to citizenship. This burdens domestic facilities and creates resentment on the part of locals, who see it not only as placing undue burden on their facilities but also a way to take advantage of a system paid for with their taxes.

\section{Negative spillovers from FDI}

The broad literature reports a crowding effect of FDI, where local players initially lose market share but later recover to benefit from linkages with foreign investors (Cantwell, 1989). While there is no direct confirmation of that in healthcare, potential spillovers seem limited to cross-border joint ventures. The foreign party may not wish to cooperate, however, as it targets a different set of customers. In addition, as already noted, with little ability to judge quality, patients rely on branding and/or a country-of-origin effect, and may thus view a joint service, especially in a developing market, as compromising quality.

\section{IMPLICATIONS FOR THEORY AND POLICY}

Boddewyn et al. (1986: 54) opine that "specific analyses of each service subsector should prove more fruitful than the creation of a general category of "service MNEs" in view of the heterogeneity of this group." We agree. Further, we believe that IB researchers need to prioritize certain service subsectors, and that healthcare should be given priority considering its significant theoretical and policy implications. In this section, we reflect on how healthcare internationalization fits with and can inform IB and theory, provide policy recommendations, and propose a future research agenda.

\section{Theoretical Implications}

The Hecksher-Ohlin theorem argues that nations will export what they have in abundance and import what they are short of (Heckscher, 1949; Ohlin, 1933). From that perspective, the United 
States is expected to receive foreign patients from a developing country that lacks advanced care, as it does. Linder's (1961) income-preference similarity theory suggests that the more similar the product demand in a pair of countries, the more trade will occur between the two. While the theory primarily separates agricultural and manufacturing goods, it is applicable to services, healthcare included. The new trade theory holds that interindustry trade is governed by the Hecksher-Ohlin theorem, while intra-industry trade is explained by industry specialization. Healthcare trade fits well with this perspective as well as with the human skills approach, which argues that, in a modern economy, national comparative advantage lies more in workforce skills than in physical endowments. While extant frameworks can explain the two-way patient flow between developed and developing nations, they do not explain the surge in developed country patients obtaining care in emerging markets. In medical tourism, availability, price, and quality matter, and trade is primarily for "high value-added" services, for which costs of international flights and accommodation are viable. Still, when it comes to severe and fatal diseases, where the potential benefit - human life and quality of life - is of the utmost value, cost considerations, while relevant, may take a back seat.

A corollary to the above observation is that traditional industry categorization may be too limited to capture the enigma of healthcare. Take, for instance, the difficulty to ascertain quality, a key feature of the sector. North writes that "if it is difficult to measure the valued attributes in exchange for goods and services, the problems between principals and agents are even more serious" (1984: 9). In theory, this should give rise to internalization, creating an internal market to compensate for market imperfections (Dunning, 1980), especially where quality and quality control are paramount, which should give rise to MNEs (Casson, 1982). Why is it, then, that we do not see, at least so far, many large healthcare MNEs? Other factors may be at play. In the Boddewyn et al. (1986) terminology, healthcare is a location-bound service. New technologies notwithstanding, this is still the case. Healthcare MNEs rely on a large cadre of expatriate staff, which is consistent with Rugman's (1981) view that knowledge is the most important firm-specific advantage. However, unless a locality is specifically associated with health (Weisz, 2011) or benefits from a diaspora relationship, it is difficult to see what a low-income host-country brings to the table.

The healthcare sector represents an opportunity to revisit the seminal question of why MNEs exist (Buckley \& Casson, 1976). We find a relatively limited number of healthcare MNEs, few on the scale seen in manufacturing or other services. One interpretation is that this is a product of the late globalization of the sector and the multitude of institutional obstacles that stand in the way. Those obstacles limit opportunities to scale-up operations - both at home and internationally - and, in turn, reduce the ability to learn from a firm's own experience and/or from the experience of others. Given healthcare's unique features, this increases the probability that any learning that does occur might be erroneous, since it will be based on MNEs' experience in sectors that are fundamentally different.

Contractor (2012) argues that being multinational is generally superior to remaining in the home base, but acknowledges that certain contingencies may introduce exceptions to this rule, which, in turn, explains the bewildering range of inconsistent results on the profitability of internationalization. While highlighting country-specific and firm-specific contingencies that undermine the allure of international expansion, Contractor is critical of multi-industry research designs that obscure the possible impact of industry. Healthcare, we propose, is a case in point. Due to the sanctity of life and its public good positioning, demand is mostly inelastic, so economy of scale and diversification may not be a driver of international expansion (Rugman, 1976), and the efficiency-seeking motivation seems less alluring.

Discussing the internationalization of the service sector, Boddewyn et al. (1986: 54) conclude that "no special FDI-MNE theories for international service firms are necessary". Still, Li and Guisinger (1992) identify a number of important features differentiating MNEs in the service sector from their manufacturing brethren, and Campbell and Verbeke (1994) resolve that the strategic capabilities required of service MNEs differ from those of manufacturing MNEs. Rajshekhar et al. (2001) find that, in service MNEs, like in manufacturing firms, firm size and market characteristics are drivers of internationalization, but competitive advantage is not. Healthcare may pose a further challenge, in the sense that a technological edge can only be approximated via reputational signals that are 
often domestic, which may limit the ability of firms to grow into large MNEs.

\section{Policy Recommendations}

Healthcare is high on the agenda of many national governments. The sanctity of life and the perception of healthcare as a public good translate into higher expectations for a quality service at an affordable price. Unfortunately, the role of trade and FDI in the sector and its potential contribution to what many see as a healthcare crisis is not often considered. Internationalization is indeed a doubleedged sword, but done right it can do for healthcare what it has done for other sectors before, namely enhance productivity and growth to the benefit of many and, eventually, most. In view of the institutional obstacles and spillovers, positive and negative, highlighted in this paper, governments in home and host-countries, developed and developing alike, need to consider how to improve institutions and policies to better leverage resources, minimize risk, and maximize the benefits of trade and FDI in healthcare.

That healthcare possesses unique features and faces special obstacles does not negate its positive potential, but requires still higher cross-border synchronization than in other sectors. At the bilateral and regional levels, (re)negotiation of trade and investment agreements needs to incorporate this sector for its unique aspects and needs. At the multilateral level, the current agreement for services trade, namely the GATS, is insufficient. International organizations, such as the WTO, should take the lead in envisaging a framework for global cooperation in trade and FDI in healthcare. The ongoing plurilateral negotiation of the Trade in Services Agreement could also play an instrumental role in this regard. If the COVID-19 pandemic has taught us anything, it is that unitary national efforts can only do so much and that international cooperation is crucial.

\section{REFERENCES}

Aitken, B. J., Hanson, G. H., \& Harrison, A. E. 1994. Spillovers, foreign investment, and export behavior. National Bureau for Economic Research (NBER) Working Paper \#4967.

Aitken, B., \& Harrison, A. 1994. Do domestic firms benefit from foreign direct investment? Policy Research Working Paper \#1248. Washington: The World Bank.

Al-Amin, M., Makarem, S. C., \& Pradhan, R. 2011. Hospital ability to attract international patients: A conceptual framework. International Journal of Pharmaceutical and Healthcare Marketing, 5(3): 205-221.

\section{Suggestions for Further Research}

In the same way that IB researchers are (hopefully) drawn to Africa as the "last frontier" for trade and FDI, they should consider studying healthcare as a last sectoral frontier. Not only will scholars learn about a sector which has been growing in share and importance in most national economies but they will also be able to test and refine our extant theories and methodologies. Whereas the importance of the sector for individuals and their communities is self-evident, researchers may also tap the opportunity to follow a sample sector and from the early phases of its globalization, thus closely observing what in other sectors may only be studied retrospectively. If this leads us to do more longitudinal research and to take a longer-term horizon in research, it may be an added bonus.

We also recommend investigating healthcare trade and FDI from a comparative perspective, by which we mean not only comparison of different country pairs (investing vs recipient countries; exporters vs importers; developed vs developing countries) but also concomitant interindustry and intermode comparisons. Given how modes of service provision are intertwined, they need to be examined in a comprehensive manner, comparing modal profiles. We encourage company and country case studies and policy-oriented research on healthcare, aiming to improve relevant institutions at both national and international levels. With the right institutions in place, trade and FDI in healthcare are not the problem, but can be part of the solution, enhancing well-being the world over.

\section{ACKNOWLEDGEMENTS}

The authors would like to thank Professor Alain Verbeke, Professor Stav Fainshmidt and two anonymous reviewers for their very helpful guidance.

ASEAN Secretariat \& UNCTAD. 2019. ASEAN investment report 2019: FDI in services: Focus on health care. ASEAN Secretariat \& UNCTAD, October 2019.

Bertinato, L., Busse, R., Fahy, N., Legido-Quigley, H., McKee, M., Palm, W., Passarani, I., \& Ronfini, F. 2005. Cross-border health care in Europe. Policy brief. Geneva: World Health Organization.

Blomström, M. 1989. Foreign investment and spillovers. London: Routledge. 
Boddewyn, J. J., Halbrich, M. B., \& Perry, A. C. 1986. Service multinationals: Conceptualization, measurement and theory. Journal of International Business Studies, 17(3): 41-57.

Buckley, P. J., \& Casson, M. 1976. The future of the multinational enterprise. London: Macmillan.

Buckley, P. J., Clegg, J., \& Wang, C. 2002. The impact of inward FDI on the performance of Chinese manufacturing firms. Journal of International Business Studies, 33(4): 637-655.

Campbell, A. J., \& Verbeke, A. 1994. The globalization of service multinationals. Long Range Planning, 27(2): 95-102.

Cantwell, J. 1989. Technological innovation and multinational corporations. Oxford: Blackwell.

Casson, M. C. 1982. Transaction costs and the theory of the multinational enterprise. In A. M. Rugman (Ed.), New theories of the multinational enterprise: 24-43. New York: St. Martin's Press.

Caves, R. E. 1971. International corporations: The industrial economics of foreign investment. Economica, 38, 1-27.

Center for Disease Control and Prevention (CDC) 2018. CDC yellow book 2018: Health information for international travel. Oxford: Oxford University Press.

Chanda, R. 2002. Trade in health services. Bulletin of the World Health Organization, 80(2): 158-163.

Chaulagain, S., Pizam, A., \& Wang, Y. 2020. An integrated behavioral model for medical tourism: An American perspective. Journal of Travel Research (online prepublication).

Cheung, K. Y., \& Lin, P. 2004. Spillover effects of FDI on innovation in China: Evidence from the provincial Data. China Economic Review, 15(1): 25-44.

Clark, T., Rajaratnam, D., \& Smith, T. 1996. Toward a theory of international services: Marketing intangibles in a world of nations. Journal of International Marketing, 4(2): 9-28.

Contractor, F. J. 2012. Why do multinational firms exist? A theory note about the effect of multinational expansion on performance and recent methodological critiques. Global Strategy Journal, 2: 318-331.

Cutler, D. M., \& Richardson, E. 1998. The value of health: 1970-1990. American Economic Review, 88(2): 97-100.

Dalen, J. E., \& Alpert, J. S. 2018. Medical tourists: Incoming and outgoing. American Journal of Medicine, 132(1): 9-10.

Damijan, J. P., Rojec, M., Majcen, B., \& Knell, M. 2013. Impact of firm heterogeneity on direct and spillover effects of FDI: Micro-evidence from ten transition countries. Journal of Comparative Economics, 41(3): 895-922.

Du, L., Harrison, A., \& Jefferson, G. H. 2012. Testing for horizontal and vertical foreign investment spillovers in China, 1998-2007. Journal of Asian Economics, 23(3): 234-243.

Dunning, J. H. 1980. Toward an eclectic theory of international production. Journal of International Business Studies, 11: 9-31.

Dunning, J. H., \& McQueen, M. 1982. The eclectic theory of multinational enterprise and the international hotel industry. In A. M. Rugman (Ed.), New theories of the multinational enterprise: 79-106. New York: St. Martin's Press.

Dunning, J. H., \& Norman, G. 1983. The theory of the multinational enterprise: An application to multinational office location. Environment and Planning A, 15: 675-692.

Economist. 2020. Mercy and money. April 4: 25.

Fetscherin, M., \& Stephano, R. M. 2016. The medical tourism index: Scale development and validation. Tourism Management, 52(1): 539-556.

Fregidou-Malama, M., \& Hyder, A. S. 2015. Impact of culture on marketing of health services - Elekta in Brazil. International Business Review, 24(3): 530-540.

Glinos, I. A., \& Wismar, M. (Eds.). 2013. Hospitals and borders: Seven case studies on cross-border collaboration and health system interactions. Geneva: World Health Organization.

Goerzen, A., \& Makino, S. 2007. Multinational corporation internationalization in the service sector: A study of Japanese trading companies. Journal of International Business Studies, 38(7): 1149-1169.
Govinda, R., \& Poornima, M. (Eds.). 2020. India's social sector and SDGs: Problems and prospects. London: Routledge.

Grossman, G., \& Helpman, E. 1991. Innovation and growth in the global economy. Cambridge: MIT Press.

Haddad, M., \& Harrison, A. 1993. Are there positive spillovers from direct foreign investment? Journal of Development Economics, 42: 51-74.

Hall, R. E., \& Jones, C. I. 2004. The value of life and the rise in health spending. NBER Working Paper \#10737.

Harrison-Walker, L. J. 1995. The relative effects of national stereotype and advertising information on the selection of a service provider: An empirical study. Journal of Services Marketing, 9(1): 47-59.

Hasenfeld, Y. 1972. People processing organizations: An exchange approach. American Sociological Review, 37(3): 256-263.

Havranek, T., \& Irsova, Z. 2012. Survey article: Publication bias in the literature on foreign direct investment spillovers. Journal of Development Studies, 48(10): 1375-1396.

Heckscher, E. 1949. The effects of foreign trade on the distribution of income. In H. Ellis, \& L. Metzler (Eds.), Readings in the theory of international trade: 272-300. Westfield Geelong: Blakiston.

Hejazi, W., \& Safarian, A. E. 1999. Trade, foreign investment, and R\&D Spillovers. Journal of International Business Studies, 30(3): 491-511.

Herman, L. 2009. Assessing international trade in healthcare services. Working Paper. Brussels: European Centre for International Political Economy.

Hitt, M. A., Tihanyi, L., Miller, T., \& Connelly, B. 2006. International diversification: Antecedents, outcomes, and moderators. Journal of Management, 32(6): 831-867.

Holden, C. 2005. The internationalization of corporate healthcare: Extent and emerging trends. Competition \& Change, 9(2): 201-219.

Hymer, S. 1960. The international operation of national firms: $A$ study of direct foreign investment. Ph.D. dissertation published in 1976, MIT Press, Cambridge, MA.

Javalgi, R., Griffith, D. A., \& White, S. 2003. An empirical examination of factors influencing the internationalization of service firms. Journal of Service Marketing, 17(2): 185-201.

Johanson, J., \& Vahlne, J. E. 1977. The internationalization process of the firm - A model of knowledge development and increasing foreign market commitment. Journal of International Business Studies, 8(1): 23-32.

Khorana, S. 2016. International trade in the health sector: Forgotten frontier? (p. 126). Commonwealth Trade Hot Topics.

Koizumi, T., \& Kopecky, K. J. 1977. Economic growth, capital movements and the international transfer of technical knowledge. Journal of International Economics, 7: 45-65.

Lautier, M. 2014. International trade of health services: Global trends and local impact. Health Policy, 118: 105-113.

Lesher, M., \& Miroudot, S. 2008. FDI spillovers and their interrelationships with trade. Trade Policy Working Paper \#80. Paris: OECD.

Lethbridge, J. 2011. Understanding multinational companies in public health systems using a competitive advantage framework. Globalization and Health, 7: 1-19.

Lethbridge, J. 2015. Health care reforms and the rise of global multinational health care companies. Briefing paper for the Public Services International Research Unit.

Li, J., \& Guisinger, S. 1992. The globalization of service multinationals in the "triad" regions: Japan, Western Europe and North America. Journal of International Business Studies, 23(4): 675-696.

Liang, G. 2004. New competition: Foreign direct investment and industrial development in China. Rotterdam: Erasmus Research Institute of Management.

Linder, S. B. 1961. An essay on trade and transformation. New York: Wiley. 
Lunt, N., Smith, R., Exworthy, M., Green, S. T., Horsfall, D., \& Mannion, R. 2010. Medical tourism: Treatments, markets and health system implications: A scoping review. Paris: OECD.

Mann, M. 2017. Exploratory estimates of US international services by mode of supply. Working Paper. U.S. Bureau of Economic Analysis.

Markusen, J. R. 1984. Multinationals, multi-plant economies, and the gains from trade. Journal of International Economics, 16(3): 205-226.

Mattoo, A., \& Rathindran, R. 2006. How health insurance inhibits trade in healthcare. Health Affairs, 25(2): 358-368.

Mills, P. K., \& Morris, J. H. 1986. Clients and "partial" employees of service organizations: Role development in client participation. Academy of Management Review, 11(4): 726-735.

Mortensen, J. 2008. International trade in health services: assessing the trade and the trade-offs. Working Paper \#2008/11. Denmark: Danish Institute for International Studies.

North, D. C. 1984. Transaction costs, institutions, and economic history. Journal of Institutional and Theoretical Economics, 140: 7-17.

Oh, C. H., Kim, M., \& Shin, J. 2019. Paths and geographic scope of international expansion across industries. International Business Review, 28(3): 560-574.

Ohlin, B. 1933. Interregional and international trade. Cambridge: Harvard University Press.

Outreville, J. F. 2007. Foreign direct investment in the healthcare sector and most-favored locations in developing countries. European Journal of Health Economics, 8: 305-312.

Pérez, P. F. 2020. Partners in a journey to the center of the world: Spanish and Japanese knowledge transfer and alliances in the Japanese healthcare industries. Business History, 62(7): 1202-1230.

Rajshekhar, G. J., Cutler, B. D., \& Winans, W. A. 2001. At your service! Does country of origin research apply to services? Journal of Services Marketing, 15(7): 565-582.

Reading, J. P. 2010. Who's responsible for this? The globalization of healthcare in developing countries. Indiana Journal of Global Legal Studies, 17(2): 367-387.

Romer, P. M. 1986. Increasing returns and long-run growth. Journal of Political Economy, 94(5): 1002-1037.

Ruane, F., \& Ugur, A. 2004. Foreign direct investment and productivity spillovers in Irish manufacturing industry: Evidence form plan level panel data. International Journal of the Economics of Business, 11(3): 53-66.

Rueda-Cantuche, J. M., Kerner, R., Cernat, L., \& Ritola, V. 2016. Trade in services by GATS modes of supply: Statistical concepts and first EU estimates. Chief Economist Note, 3. Brussels: European Commission.

Rugman, A. 1976. Risk reduction by international diversification. Journal of International Business Studies, 7: 75-80.

Rugman, A. 1981. Inside the multinationals. New York: Columbia University Press.

Samiee, S. 1999. The internationalization of services: Trends, obstacles and issues. Journal of Services Marketing, 13(4/5): 319-328.

Shenkar, O., Tallman, S., Wang, H., \& Wu, J. 2020. National culture and international business: A path forward. Journal of International Business Studies (online publication).

Smeets, R. 2008. Collecting the pieces of the FDI knowledge spillover puzzle. The World Bank Research Observer, 23(2): 107-138.

Smith, R. D., Álvarez, M. M., \& Chanda, R. 2011. Medical tourism: A review of the literature and analysis of a role for bilateral trade. Health Policy, 103(2/3): 276-282.
Smith, R. D., Chanda, R., \& Tangcharoensathien, V. 2009. Trade in health-related services. The Lancet, 373: 593-601.

Sorensen, J. E., \& Sorensen, T. L. 1974. The conflict of professionals in public bureaucracies. Administrative Science Quarterly, 19(1): 98-106.

Stevens, P., Urbach, J., \& Wills, G. 2013. Healthy trade: The relationship between open trade and health. Foreign Trade Review, 48(1): 125-135.

Telegraph. 2018. NHS to be franchised around the globe under post-Brexit plans. September 10.

Thompson, J. D. 1967. Organizations in action: Social science bases of administrative theory. New York: McGraw-Hill.

Toyne, B., \& Nigh, D. 1998. A more expansive view of international business. Journal of International Business Studies, 29(4): 863-876.

UNCTAD (United Nations Conference on Trade and Development). 2001. World investment report 2001: Promoting linkages. New York \& Geneva: United Nations.

UNCTAD. 2004. World investment report 2004: The shift towards services. New York \& Geneva: United Nations.

Uner, M. M., Cetin, B., \& Cavusgil, S. T. 2020. On the internationalization of Turkish hospital chains: A dynamic capabilities perspective. International Business Review (online prepublication).

Vandermerwe, S., \& Chadwick, M. 1989. The internationalization of services. The Service Industries Journal, 9(1): 79-93.

Wei, Y., Liu, X., \& Wang, C. 2008. Mutual productivity spillovers between foreign and local firms in China. Cambridge Journal of Economics, 32(4): 609-631.

Weisz, G. 2011. Historical reflections on medical travel. Anthropology and Medicine, 18(1): 137-144.

Wettstein, S., Liberatore, A., Magdeleine, J., \& Maurer, A. 2019. A global trade in services data set by sector and by mode of supply. Geneva: World Trade Organization.

World Tourism Organization 2016. World tourism barometer and statistical annex, 14. Madrid: World Tourism Organization.

Zeithaml, V. A. 1981. How consumer evaluation processes differ between goods and services. In I. H. Donnelly, \& W. R. George (Eds.), Marketing of services: 186-190. New York: American Marketing Association.

\section{ABOUT THE AUTHORS}

Oded Shenkar is Ford Motor Company Chair in Global Business Management, and Professor of Management and Human Resources and Academic Director of the National Center for the Middle Market, at the Fisher College of Business, Ohio State University. He is the author of numerous books and more than 120 articles, and is a Fellow and Past Vice President of the Academy of International Business.

Guoyong Liang is Economic Affairs Officer at the Division on Investment and Enterprise of the United Nations Conference on Trade and Development. He holds a PhD from the Rotterdam School of Management, Erasmus University. $\mathrm{He}$ is an 
author of 14 issues of World Investment Report, and has published widely with a focus on international economic relations and development.
Rakefet Shenkar is an MD candidate at the Boonshoft School of Medicine, Wright State University, in Dayton, Ohio.

Publisher's Note Springer Nature remains neutral with regard to jurisdictional claims in published maps and institutional affiliations.

Accepted by Stav Fainshmidt, Consulting Editor, 5 April 2021. This article has been with the authors for two revisions. 